\title{
Interdependence of Museums and Tourism Industry in Jordan
}

\author{
Nermin Khasawneh \\ Queen Rania Faculty of Tourism and Heritage, Hashemite University \\ P.O. Box 330127 Postal Code 13133 Zarqa, Jordan \\ Tel: 962-77-551-3936 E-mail: nermin@hu.edu.jo
}

Received: Nov. 30, 2018 Accepted: Jan. 14, $2019 \quad$ Published: January 14, 2019

doi:10.5296/jmr.v11i1.14201ＵRL: https://doi.org/10.5296/jmr.v11i1.14201

\begin{abstract}
Museums are educational, cultural and recreational centers; cares for objects of scientific, artistic, cultural, or historical value and other artifacts linked to the cultural and popular heritage of particular people, exhibiting and preserving these collections for subsequent generations. Heritage is the basis of civilization as it represents the nation's memory and a bridge linking its authenticity with its present and future as well as the foundations of its representation and identity. The aims of this retrospective study are to review the consistence and historical development of the Jordanian museums and to evaluate its current status, its contribution in sustainable tourism industry and to adjoin a new contribution to the current knowledge in this field. This study based on two approaches; the first was conducted on the numbers of visitors to five selected museums in Jordan for the years 2016-2017, taking into account the residence variable. The second approach used a sort specially designed questionnaires, written in Arabic and English languages were given non- selectively to (120) visitors, designed to determine the role of museums in supporting tourism in Jordan. Data were collected and a descriptive analysis was performed. The findings of this study revealed that museums play a prominent role in supporting the tourism industry through its active educational and recreational activities (94.33\%), supporting domestic tourism (92.67\%), and promote loyalty and national identity $(92.33 \%)$. Our study confirmed the vital role of museums in the tourism industry, which in turn provides a fundamental tributary to the Jordanian Gross Domestic Product. The diversified Jordanian museums with its authentic holdings, in addition to the unique tourist destinations call for immediate support to boost Jordanian tourism globally.
\end{abstract}

Keywords: Museums, Tourism Industry, Domestic Tourism, cultural Heritage. 


\section{Introduction}

According to the ICOM Statutes, adopted by the 22nd General Assembly in Vienna, Austria, on 24 August, 2007: A museum is a non-profit, permanent institution in the service of society and its development, open to the public, which acquires, conserves, researches, communicates and exhibits the tangible and intangible heritage of humanity and its environment for the purposes of education, study and enjoyment(ICOM, 2007). Museums are institutions dedicated to the acquisition, conservation, study, exhibition, and educational interpretation of collection shaving cultural, historical, scientific or artistic significance and presenting through temporary or permanent exhibitions. The digital transformation has led to the upgrading of traditional museums to include virtual exhibits with high quality images of its collections for perusal, study, and exploration by Internet. In addition, museums are involved in peace education and intercultural understanding (Johan, N., \& M. Joppe. 2005).Tourism industry in Jordan faces many different challenges, including regional political turmoil with its social implications, the global economic crisis and continued competition with other sectors. Therefore, the tourism industry was committed to adapting to these challenges, which inevitably affect the demand in this sector, along with trying to reform the economic and social aspects of the current sector structure. The objectives of this retrospective study are to review the Jordanian museums and evaluate its role in the sustainable tourism industry. This study added a new contribution to the current literature in this field, despite the lack of previous local studies and the scarcity of relevant sources. Moreover, a detailed study of the reciprocal relationships between museums and the tourism industry can offer preventive solutions to overcome future challenges.

\section{The emergence of museums in Jordan and its historical development}

Jordan's experience in the museum sector is a relatively deep. The Jerash Archaeological Museum was established in 1923 (Malt, 2002), then The Jordan Archaeological Museum (Citadel Hill), which was established by the Department of Antiquities (DOA) in 1951(Zaghloul, 1994).Jordan has recognized the importance of museums and its cultural and social role, as well as its importance in supporting the components of national income. In the 1960s, two museums were established: the Archaeological Museum (University of Jordan), which was the first educational museum, and Petra Archaeological Museum (Malt, 2002). The inception of museums was concomitant with the initial establishment of the Jordanian state; politically, economically and socially. Early museums were limited to the archaeological and heritage types. Gradually, with the further establishment of the State; museums were developed in its numbers and types where military themes and artistic objects were incorporated and more museums have been set up in Ajloun, Aqaba, Ma'an and Mafraq (Naghway, 2007). Nowadays, Jordan has a plenty of many advanced and non-traditional museums, these scientific, cultural and educational beacons preserve the national heritage as a part of the human cultural heritage. Jordanian museums can be categorized into six main groups, by applying a typing based on (Ambrose and Paine, 2006); archaeology, heritage, history, science and technology, natural sciences, natural history, and fine art museums. It is worth mentioning that, modern museums have become diversified in its tasks and collections, as each museum is a mix of genres and there is no museum limited to only a single style. 
These museums are distributed in most areas of the Kingdom to cope with various aspects that fit the concept of social style (Majdoubeh \& Sweiss, 2002).Table 1 shows the name, location, type and date of establishment of Jordanian museums.

Table 1. Name, Location, Type and Establishment Date of Jordanian Museums

\begin{tabular}{|c|c|c|c|c|}
\hline \multicolumn{2}{|c|}{ Name of Museum } & \multirow{2}{*}{$\begin{array}{c}\text { Location } \\
\text { Jerash }\end{array}$} & \multirow{2}{*}{$\begin{array}{c}\begin{array}{c}\text { Establishment } \\
\text { Date }\end{array} \\
1923 \\
\end{array}$} & \multirow{2}{*}{$\begin{array}{c}\text { Types } \\
\text { Archaeological } \\
\end{array}$} \\
\hline 1 & Jerash Archaeological Museum & & & \\
\hline 2 & Jordan Archaeological Museum & Amman/Citadel Hill & 1951 & Archaeological \\
\hline 3 & The Archaeological Museum & $\begin{array}{c}\text { Amman / University } \\
\text { of Jordan }\end{array}$ & 1962 & Educational \\
\hline 4 & Petra Archaeological Museum & Petra & 1963 & Archaeological \\
\hline 5 & $\begin{array}{c}\text { The Jordanian Museum of } \\
\text { Popular Traditions }\end{array}$ & $\begin{array}{l}\text { Amman/ Downtown, } \\
\text { Roman theater }\end{array}$ & 1971 & Traditional \\
\hline 6 & Mazar Islamic Museum & Al-Karak & 1973 & Islamic \\
\hline 7 & Jordan Folklore Museum & Amman & 1975 & Traditional \\
\hline 8 & Botany Museum & $\begin{array}{c}\text { Irbid/Yarmouk } \\
\text { University }\end{array}$ & 1976 & Botanical \\
\hline 9 & $\begin{array}{c}\text { Martyr's Memorial and Military } \\
\text { Museum }\end{array}$ & Amman/Sport City & 1977 & Military \\
\hline 10 & The Anthropological Museum & $\begin{array}{c}\text { Amman / University } \\
\text { of Jordan }\end{array}$ & 1977 & Traditional \\
\hline 11 & $\begin{array}{c}\text { Madaba Archaeological } \\
\text { Museum } \\
\end{array}$ & Madaba & 1979 & Archaeological \\
\hline 12 & $\begin{array}{c}\text { Madaba Museum of Jewelery } \\
\text { and Folklore }\end{array}$ & Madaba & 1979 & Traditional \\
\hline 13 & $\begin{array}{c}\text { The Jordan National Gallery of } \\
\text { Fine Arts }\end{array}$ & Amman & 1980 & Fine Arts \\
\hline 14 & Natural History Museum & $\begin{array}{c}\text { Irbid/Yarmouk } \\
\text { University } \\
\end{array}$ & 1981 & Natural History \\
\hline 15 & $\begin{array}{c}\text { Al-Karak Archaeological } \\
\text { Museum }\end{array}$ & Al-Karak & 1981 & Archaeological \\
\hline 16 & $\begin{array}{c}\text { Al-Salt Archaeological } \\
\text { Museum }\end{array}$ & Al-Salt & 1983 & Archaeological \\
\hline 17 & $\begin{array}{c}\text { The Museum of Jordanian } \\
\text { Heritage }\end{array}$ & $\begin{array}{c}\text { Irbid/Yarmouk } \\
\text { University }\end{array}$ & 1984 & Traditional \\
\hline 18 & Irbid Archaeological Museum & Irbid/city center & 1984 & Archaeological \\
\hline 19 & Umm Qais Museum & Irbid & 1987 & Archaeological \\
\hline 20 & Salt Folklore Museum & Al-Salt & 1987 & Traditional \\
\hline 21 & $\begin{array}{l}\text { The Numismatics Museum } \\
\text { Central Bank of Jordan }\end{array}$ & Amman & 1988 & Numismatics \\
\hline 22 & The Museum of Textbooks & Al-Salt & 1988 & Books \\
\hline 23 & Aqaba Archaeological & Aqaba & 1991 & Archaeological \\
\hline
\end{tabular}




\begin{tabular}{|c|c|c|c|c|}
\hline & Museum & & & \\
\hline 24 & Museum of Marine & Aqaba & 1992 & Marine \\
\hline 25 & Ajloun Museum & Ajloun & 1993 & Archaeological \\
\hline 26 & Petra Nabataean Museum & petra & 1994 & Archaeological \\
\hline 27 & Islamic Museum & Amman/ Al Abdali & 1995 & Islamic \\
\hline 28 & $\begin{array}{c}\text { Al-Mafraq Archaeological } \\
\text { Museum }\end{array}$ & Al -Mafraq & 1995 & Archaeological \\
\hline 29 & Samarqand Museum & $\begin{array}{c}\mathrm{Al} \text {-Mafraq/ AL -al } \\
\text { Bayt University }\end{array}$ & 1995 & Archaeological \\
\hline 30 & Botany Museum & $\begin{array}{c}\text { Al - Mafraq/ AL -al } \\
\text { Bayt University }\end{array}$ & 1995 & Botanical \\
\hline 31 & $\begin{array}{c}\text { Jordan Ahli Bank Numismatic } \\
\text { Museum } \\
\end{array}$ & Amman & 1999 & Numismatics \\
\hline 32 & Hijaz Railway Museum & $\begin{array}{l}\text { Amman /railway } \\
\text { station }\end{array}$ & 1999 & $\begin{array}{l}\text { Means of } \\
\text { Transport }\end{array}$ \\
\hline 33 & Islamic Numismatics Museum & $\begin{array}{c}\text { Irbid/Yarmouk } \\
\text { University } \\
\end{array}$ & 2001 & Numismatics \\
\hline 34 & The Royal Automobile Museum & Amman & 2003 & $\begin{array}{l}\text { Means of } \\
\text { Transport }\end{array}$ \\
\hline 35 & Zeus Museum & Jerash & 2004 & Archaeological \\
\hline 36 & Dead sea Museum & Madaba & 2006 & Natural history \\
\hline 37 & The Children's Museums & Amman & 2007 & Children \\
\hline 38 & Abu Jaber Museum & Al-Salt & 2010 & Traditional \\
\hline 39 & La Storia Tourism Complex & Madaba & 2013 & Traditional \\
\hline 40 & The Jordan Museum & Amman & 2009 & National \\
\hline 41 & Prophet Muhammad Museum & Amman & 2012 & Islamic \\
\hline 42 & Museum of Parliamentary Life & Amman & 2016 & Political \\
\hline 43 & Stamp Museum & Amman & 2016 & History \\
\hline 44 & Royal Tank Museum* & Amman & 2018 & Military \\
\hline
\end{tabular}

Source: Department of Antiquities; 2017.

*Ministry of

Culture

In 1999, the Directorate of Museums (DOM) in Amman was established by DOA with an overall vision to achieve a proper level of awareness of Jordan's heritage and civilization, deepens the concept of preserving this valuable heritage, and ties citizens up with Jordan's long history (Mousa, 1985), through upgrading the Jordanian museums to International Standards of Museums and presenting Jordan's culture with the best interesting means. In summary tasks and responsibilities of DOM(Ministry of Tourism \& Antiquities [MOTA], 2018), are:

- Developing presentation techniques.

- Providing suitable environmental conditions for preservation of collections. 
- Improving the provided services to visitors.

- Activating the educational role of museums and strengthen the national identity.

- Establishing temporary exhibitions inside and outside the Kingdom.

- Enhancing the efficiency of museum management.

- Application of International Standards of Museums.

- Conducting research and studies for continuous improvement of museums.

- Adopt the latest technology in documenting museum holdings.

\section{Current status of museums in Jordan}

At present, museums are distributed in most of the Kingdom's provinces, as shown in Figure 1. These museums contain large numbers of artifacts and follow the chronological sequence in the display of its holdings (MOTA, 2018).

Concomitant with the technological inventions, museums have become centers of innovations for different branches of science and arts, which has a positive reflection in enriching the museum's educational and recreational missions. Recently, some Jordanian museums have begun to use modern technologies such as audio and video presentations in dedicated halls to bring more fun and excitement to the visitors. The audio guide system enables the visitor to listen to comments on the exhibits without having to read the information on the cards accompanying the exhibits, such as the 'Royal Automobile Museum' in Amman, which is one of the most interesting and well organized museums in Jordan. This museum depicts the history of the Hashemite Kingdom of Jordan from the early 1920s until today through cars and motorcycles (Jordan times [JT], 2014).

Also, the museum of 'La Storia' in Madaba which is an attractive mixture of a folk museum, a history museum and handicrafts center at Mount Nebo aims to promote the idea of fraternity between religions (JT,2014). 


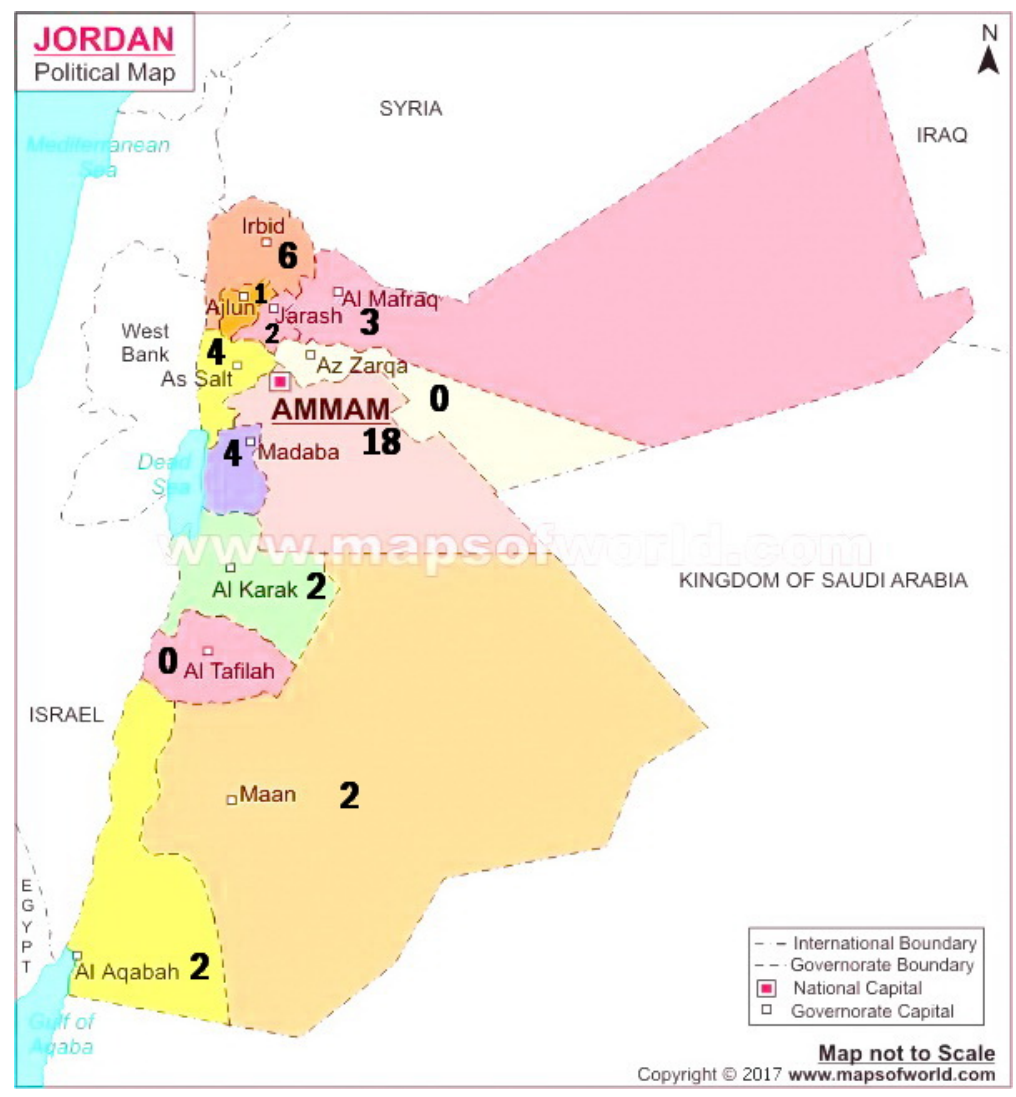

Figure 1. Distribution of museums in the Jordan

\section{Governorates}

\section{Museums of Amman}

Amman has the largest number of diverse and modern museums, as:

- The Children's Museum, a reference center for local and regional learning, as well as a creative partner for children at the international level (The children's Museum Jordan [cmj], 2018).

- The Museum of parliamentary life, one of the first examples of parliamentary museums around the world (Jordan Tourism Board [JTB], 2013).

- The Museum of Jordan, a comprehensive national center for science and knowledge and reflects the history and civilization of Jordan in an innovative educational manner (JTB, 2013).

- Stamp Museum, which includes the first group of Jordanian stamps issued in 1927(Jordan Post, 2017).

- The Museum of the Prophet Muhammad (PBUH) established in 2012, and contains a number of noble prophetic monuments (Royal Hashemite Court, 2018). 
- The Royal Tank Museum, which is the first of its kind in the Arab world and one of the largest historical museums for tanks in the world, inaugurated in 2018 (JT, 2018).

\section{Renovation and Modernization of Jordanian Museums}

One of the most prominent features in the renovation and modernization of Jordanian museums, those official endeavors that seemed more systematic and ambitious towards raising the profiles of the Jordanian museums to comply with the International Standards of Museums, these endeavors include:

- Hosting international exhibitions in Jordanian museums and presenting cultural performances in an excellent manner through interactive and non-traditional educational experiences, such as: Hosting the exhibition of "Leonardo's Machines: Italian Excellency over the centuries" at the Jordan Museum as part of the "World Science Forum 2017 Jordan", this exhibition is an introduction to the (International Conference of Jordanian Antiquities) which will be held in Florence in 2019(Prieto, 2017). In addition to the exhibition "1,001 Inventions" at the Jordan Museum (Gharaibeh, 2017).

- Loaning some of Jordanian antiquities to foreign museums, this in turn confirms Jordan's historical and archaeological status, for example Louvre Museum borrowed one of the statues of Ain Ghazal, which is of a great historical importance dating back to 10,000 BC (Goussous, 2016).

- The interest and initiative of banks and NGOs in supporting youth and community service projects to include museums.

- Initiating programs that facilitate museum visiting, such as "The Mobile Museum" program run by the Children's Museum (cmj, 2018).

- Conducting temporary museum exhibitions outside Jordan, in the framework of joint international coordination activities, such as participating in the "Jordan Through the Ages" exhibition at the Dubai Shopping Festival (DSF) in 2002((MOTA, 2018).

- Exploiting the museum's income to offer social services, organize volunteer works and take part in national and official holidays for instance, the Independence Day and Mother's Day.

- Improving the museum design to comply with international standards, as The Jordan National Gallery of Fine Arts, with open garden for displaying sculptures and artworks, this garden includes an Andalusia fountain provided by the Spanish government to the museum (al-Asad \& Zureikat, 2005).

- Carrying out the proper maintenance and comprehensive development of Jordanian museums, as the Museum of the Martyr's Memorial and Military Museum.

- Cooperation between the Ministry of Tourism, the DOA and the Tourism Promotion Authority to equip operating rooms for the tourist police to ensure good reception and treatment for all visitors. 
- Implementing of creative projects, to promote tourism careers among Jordanians youth by raising the younger generation's awareness of tourism through art, as the Mobile Art Museum. This project conducted in 2009, by the Jordan National Gallery of Fine Arts museum and financially supported by the USAID Economic Growth through Sustainable Tourism Project. HRH Princess Wijdan Al Hashemi, president of the Royal Society of Fine Arts, said the national gallery's mobile museum is a "pioneering project" not only for Jordan, but also for the whole region (Freij, 2014).

- Strengthening the international cooperation, as with;

- (The Japan Bank for International Cooperation (JBIC)) which has provided several grants through the tourism development project. These grants were exploited in the implementing of the National Museum of Jordan, the historic Salt Museum (Abu Jaber House) (Goussous, 2016), and to reconfigure the Petra Museum by the latest architectural designs to display the archaeological materials that embodies the Nabataean civilization and others that prevailed in Petra. The (JBIC) grant also included the experts, training and provision of necessary equipment, which collectively will combine a qualitative leap in tourism services and support of tourism development (JT, 2016).

- The Zeus Museum, founded in 2004, in cellars of the Zeus Temple beside the road leading to the Oval Square in the historic city of Jerash, financed and supervised by the Louvre Museum in France (World Monuments Fund, 2017).

\section{The Role of Museums in Supporting Tourism Industry in Jordan}

The Ministry of Tourism and the DOA have been keen to revive the culture of museums in the Kingdom, because of the reciprocal relationship between tourism industry and museums. Tourism plays a fundamental role in nourishing museums by attracting more visitors, at the same time, museums that enrich tourism by attracting more tourists (Leiper, 1990). The DOM works proactively to improve Jordanian museums and maintain sustainable development in this important sector.Museums are one of the major tourist attractions and a primary factor in promoting and polarization of tourism, as its various collections witness the cultural and historical revival of successive nations, at the same time, a universally accessible and useful language for all.There is a close correlation between museums and cultural tourism, where museums are a catalyst for feelings of belonging to history, so it preserves the concept of cultural heritage and national identity (Ngwira, \& Bello, (2018). Recently, studies have shown that cultural tourism is the fastest growing type of tourism, withthe museums offering different cultural contents such as: habits, customs, folklore, education, arts and traditional tourist products which contribute substantially in augmenting cultural tourism (Balan\&Vasile, 2015).Museums interact socially, culturally and economically to the community by providing new jobs and creating more investment projects in various sectors, including tourism. Moreover, museums strongly stimulate the tourism sector, especially during the tourism recession, by conducting various events and activities that feed tourism directly (Frey \& Meier, 2006).Museums play a vital role in achieving economic progress through the creating 
of infra cultural structures that attract many investments, so museums contribute to the revival and regeneration of local economic in times of economic regression (Ambrose \& Paine, 2005).Tourism is one of the main sources of foreign currency in the country and comprises about (11.5\%) of the Kingdom's GDP in the year 2017 compared to $(10.5 \%)$ for 2016,(Ammon news, 2018).

\section{Methodology}

Our study aims at studying the impact of the Jordanian museums sector in supporting tourism and proposing solutions that enhance museum's performance to contribute more effectively to the financing of sustainable tourism development.

The first approach of this retrospective study was conducted on the number of visitors to five selected museums in Jordan based on statistical tourism bulletin issued by the Jordanian Ministry of Tourism and Antiquities, taking into account the variability of residence. This theoretical approach enabled us to identify the most attractive museums, to compare the number of local visitors with foreign visitors and to determine the relative change in the numbers of visitors for the period 2016-2017. The data were collected and analyzed using SPSS software version 17 for statistical analysis (Statistical Package for Social Sciences, SPSS Inc., Chicago, Illinois, USA), the level of significance tested was $(\mathrm{P}<0.05)$. The second approach of this descriptive cross- sectional study on random visitors to five selected Jordanian Museums was a practical procedure. A short questionnaire, specially designed in Arabic and English, was given in a non-selective manner to 120 visitors, designed to determine the degree or extent of the contribution of museums in support of tourism in Jordan. Socio-demographic variables were not considered. Data processing and analysis were carried out by using descriptive statistics, including means, standard deviations (SD) and trend strength.

\section{Discussion}

Figure1 and table 1 above illustrate the followings:

1. Although, Jordanian museums diversified in its contents, themes, they mainly focused on archeology (31.82\%) and heritage (18.18\%).

2. Museums with religious connotations, such as the Museum of the Prophet Muhammad (PBUH), certainly, will encourage the concept of religious tourism.

3. The existence of unique museums dealing with distinct topics related to the geography and geology of the place such as the Dead Sea Museum.

4. It is clear that most of the Jordanian museums (40.91\%) are allocated in Amman. Most museums in the capital Amman are focused on the city center; where abundant archaeological sites, which considered as tourist attraction centers. This clearly emphasizes the complementary relationship between museums and tourism industry, where they vigorously enrich each other(Bruner, 1993). 
Recently, the tourism growth has participated in the radical changes in museums; this confirms the mutual impact between tourism and museums (Kelly, 2007), as evidenced in our study by a relative change $(10.20 \%)$ increase in the number of visitors to the Jordan Folklore Museum in 2017, as shown in table 2.

Table 2. Number of visitors to a sample of Jordanian museums by Nationality, 2016-2017

\begin{tabular}{|l|l|l|l|l|l|l|l|}
\hline \multirow{2}{*}{ Year } & Nationality & $\begin{array}{l}\text { The } \\
\text { Jordan } \\
\text { Museum }\end{array}$ & $\begin{array}{l}\text { Dead sea } \\
\text { Museum }\end{array}$ & $\begin{array}{l}\text { Madaba } \\
\text { Archaeological } \\
\text { Museum }\end{array}$ & $\begin{array}{l}\text { Jordan } \\
\text { Folklore } \\
\text { Museum }\end{array}$ & $\begin{array}{l}\text { Jordan } \\
\text { Archaeological } \\
\text { Museum/ } \\
\text { Citadel Hill }\end{array}$ & Total \\
\hline \multirow{2}{*}{$\mathbf{2 0 1 6}$} & Foreign & 10.550 & 5.330 & 6.150 & 49.000 & 68.550 & 139.580 \\
\cline { 2 - 8 } & Jordanian & 13.120 & 34.638 & 3.150 & 126.700 & 77.376 & 254.984 \\
\cline { 2 - 8 } & Total & $\mathbf{2 3 . 6 7 0}$ & $\mathbf{3 9 . 9 6 8}$ & $\mathbf{9 . 3 0 0}$ & $\mathbf{1 7 5 . 7 0 0}$ & $\mathbf{1 4 5 . 9 2 6}$ & $\mathbf{3 9 4 . 5 6 4}$ \\
\hline \multirow{2}{*}{$\mathbf{2 0 1 7}$} & Foreign & 22.614 & 7.425 & 7.650 & 50.900 & 128.650 & 217.239 \\
\cline { 2 - 8 } & Jordanian & 40.350 & 14.945 & 3.800 & 164.650 & 73.350 & 297.095 \\
\cline { 2 - 8 } & Total & $\mathbf{6 2 . 9 6 4}$ & $\mathbf{2 2 . 3 7 0}$ & $\mathbf{1 1 . 4 5 0}$ & $\mathbf{2 1 5 . 5 5 0}$ & $\mathbf{2 0 2 . 0 0 0}$ & $\mathbf{5 1 4 . 3 3 4}$ \\
\hline
\end{tabular}

Source: Ministry of Tourism and Antiquities.

Table 2 shows that the number of Jordanian visitors is more than the number of foreign visitors to a sample of Jordanian museums in the years 2016-2017, with a statistically significant difference $(\mathrm{P}<0.05)$ which indicates the importance of museums to the local community, at the same time it calls for the promotion of Jordanian museums internationally and enhancing Jordan as a favorable tourist destination.

Table 2 also shows that most of museum visitors focused on the Museum of Jordan Folklore in the city center of the capital Amman compared to other museums, which is of course an archaeological and tourist site. This is consistent with previous studies, which indicated that the proximity of the museum at the archaeological site plays an important role in attracting more tourists to visit the museum (Steven\& Simon, 1999). Therefore, the management of archaeological sites in Jordan had considered that and joined the entrance fees for both in one ticket.

It is worth mentioning that the Jordanian tourism sector achieved many positive indicators despite the unstable political situation in the region, as evidenced in the increased total number of visitors to a sample of Jordanian museums by $(13.8 \%)$ in the year 2017 compared with that in 2016, as shown in table 3. 


\section{Macrothink}

Table 3. Relative change in the number of visitors to a sample of Jordanian museums for the years 2016-2017

\begin{tabular}{|c|c|c|}
\hline \multicolumn{2}{|c|}{ Relative change2016-2017 } \\
\hline Foreign & Jordanian & Total \\
\hline $21.76 \%$ & $7.63 \%$ & $13.8 \%$ \\
\hline
\end{tabular}

Source: Author

Table 3 also shows the relative change in the number of visitors to a sample of Jordanian museums in the years 2016-2017, there is a significant increase in the demand of foreign tourists to visit museums in Jordan, specially the Jordan Archaeological Museum/ Citadel Hill and The Jordan Museum, this confirms one of the important achievements of the National Strategy for Tourism 2011-2015, in addition to the remarkable efforts played by The Jordan Tourism Board JTB in using the best marketing strategies to place Jordan on the world tourism map.

The indicators of the tourism sector in the Kingdom during 2017 have exceeded all expectations and Jordan's tourist income was about 3 billion dinars. The Kingdom's tourism revenues grow to (2.989) billion dinars between January and the end of November of 2017 compared to (2.650) billion dinars for the same period of 2016, increased by (12.8\%). This remarkable increase resulted from the increased total number of tourists by $(8.9 \%)$ compared with the same period of 2016. Meanwhile, the number of overnight tourists until the end of November of the year 2017 was about (3.911) million tourists compared to (3.574) million tourists during the same period of 2016, an increased by (9.5\%), (Bani Mustafa, 2017). According to preliminary data issued by the Central Bank of Jordan (CBJ), tourism revenues have increased by (15.4\%)at the end of August 2018, achieving \$3.6 billion (about JD2.565 billion), compared to around $\$ 3.1$ billion recorded in the same period of 2017 , this rise is due to the increased number of tourists by $(10.5 \%)$ compared with the same period of 2017(JT, 2018).The tourism revenues have increased by (23.3\%) for August 2018, to achieve 487 million JD, compared to the same month of 2017, (Ammon, 2018).

The second approach of our study carried out via a special questionnaire based assessment to estimate the extent or degree of the contribution of museums in supporting the tourism industry in Jordan, as explained in table 4. 
Table 4. The study assessment questionnaires were presented to 120 visitors and the descriptive parameters (Arithmetic mean, standard deviation and trend strength) were analyzed

\begin{tabular}{|c|c|c|c|c|c|c|c|c|c|c|c|}
\hline & & & & & tral & Not & gree & & & & \\
\hline 自 & Study Questions & 离 & $\%$ & ఏ & $\%$ & 离 & $\%$ & 莺 & 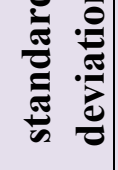 & 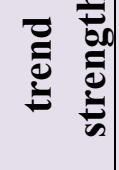 & 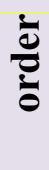 \\
\hline 1 & $\begin{array}{l}\text { Do museums achieve economic } \\
\text { development in tourist areas and } \\
\text { support the national economy? }\end{array}$ & 78 & 65 & 26 & 21.7 & 16 & 13.3 & 2.52 & 0.72 & 84.00 & 6 \\
\hline 2 & $\begin{array}{l}\text { Do museums contribute in } \\
\text { highlighting the Jordan's tourism } \\
\text { worldwide? }\end{array}$ & 55 & 45.8 & 43 & 35.8 & 22 & 18.3 & 2.28 & 0.75 & 76.00 & 9 \\
\hline 3 & $\begin{array}{l}\text { Do you think the museums alone } \\
\text { are capable of attracting tourists? }\end{array}$ & 61 & 50.8 & 47 & 39.2 & 12 & 10 & 2.41 & 0.66 & 80.33 & 8 \\
\hline 4 & $\begin{array}{l}\text { Do museums positively motivate } \\
\text { the visitors' thoughts? }\end{array}$ & 72 & 60 & 32 & 26.7 & 16 & 13.3 & 2.47 & 0.72 & 82.33 & 7 \\
\hline 5 & $\begin{array}{l}\text { Do you think that Jordanian } \\
\text { museums play a role in the } \\
\text { teaching of peace and the } \\
\text { promotion of a prosperous } \\
\text { faith-based tourism? }\end{array}$ & 77 & 64.2 & 29 & 24.2 & 14 & 1.7 & 2.53 & 0.69 & 84.33 & 5 \\
\hline 6 & $\begin{array}{l}\text { Have you detect any role of the } \\
\text { museums in attracting more } \\
\text { visitors to archaeological sites? }\end{array}$ & 87 & 72.5 & 30 & 25 & 3 & 2.5 & 2.70 & 0.51 & 90.00 & 4 \\
\hline 7 & $\begin{array}{l}\text { Have you gained any educational } \\
\text { or recreational benefits from the } \\
\text { museum visit? }\end{array}$ & 101 & 84.2 & 17 & 14.2 & 2 & 1.7 & 2.83 & 0.42 & 94.33 & 1 \\
\hline 8 & $\begin{array}{l}\text { Do you agree that museums } \\
\text { contribute in supporting domestic } \\
\text { tourism? }\end{array}$ & 96 & 80 & 21 & 17.5 & 3 & 2.5 & 2.78 & 0.47 & 92.67 & 2 \\
\hline 9 & $\begin{array}{l}\text { Do you think that museums link } \\
\text { people to their history and } \\
\text { promote loyalty and national } \\
\text { identity? }\end{array}$ & 98 & 81.7 & 21 & 17.5 & 3 & 2.5 & 2.77 & 0.53 & 92.33 & 3 \\
\hline & neral average & & & & & & & 2.58 & 0.23 & 86.14 & - \\
\hline
\end{tabular}


The general average of the questionnaires based assessment focused on the objective "The role of museums in supporting tourism in Jordan" reached (2.58), the standard deviation (0.23), and the trend strength $(86.14 \%)$. This obviously means that the sample's trend towards the objective is a high positive approval. According to the response of the study sample, the questions with most positive approval are; (Have you gained any educational or recreational benefits from the museum visit?), (Do you agree that museums contribute in supporting domestic tourism?) and (Do you think that museums link people to their history and promote loyalty and national identity?), with a trend strength (94.33\%), (92.67\%), (92.33\%), respectively. This emphasizes the importance of museums in education and entertainment, this finding is coincident with a previous study of Touche (1989), who verified that the main aim of visiting museums was for cultural and recreational purposes(Kelly, 2007). Our finding confirmed the contribution of museums in supporting domestic tourism and national income, and this is consistent with Bruner(1993).Museums also have a great role in linking people to their history and national identity and this is in agreement with Alivizatou (2012).

Meanwhile, the question with the least positive approval is; (Do museums contribute in highlighting the Jordan's tourism worldwide?), with a trend strength (76.00\%). This finding is in agreement with a previous study of Minchetti (2002), who pointed out in the beginning of the 21 st century, museums became struggling to maintain its audience of visitors because of the strong competition with other elements of the tourist attractions(Alivizatou, 2012). Also, our finding is in agreement with Leiper(1990), who concluded that the museums alone are not tourist attractions. This requires the utmost need to activate the role of museums in the promotion and marketing of Jordanian tourism globally (Minchetti et al., 2002).Furthermore, there is a synergy between museums and tourism industry, Jordan as with many developing countries should proactively adopt new strategic plans for the sustainable tourism industry as a potential solution for many intractable issues such as low employment rates, the need for foreign currencies, and generating higher tourism revenues.

\section{Conclusions \& Recommendations}

At present, museums are among the best tourist attractions in most countries. Therefore, museums must comply with the International Standards in its design, presentation and interpretation to protect its continued progress in the tourism industry.

Jordan has an impressive cultural heritage and a variety of fascinating museums with different connotations that promote different types of tourism, for instance; religious museums enrich the concept of religious tourism, and heritage museums promote the concept of cultural tourism. Therefore, the diversified museums boost up the country's rank on the global tourism status. Jordan as with many developing countries, should proactively adopt new strategic plans for the sustainable tourism industry as a potential solution to many intractable issues such as low employment rates, the need for foreign currencies, and generating higher tourism revenues.

Recently, with the promising patterns of Jordan's tourism; such as therapeutic, adventure, religious tourism, and conferences, the tourism sector has become the best growth prospects as a vital contributor to the Kingdom's GDP and a desirable employment destination. 


\section{Macrothink}

Journal of Management Research

ISSN 1941-899X

2019, Vol. 11, No. 1

Therefore, it is ultimately necessary to further support the domestic tourism industry and to promote unique Jordanian museums and attractive destinations for promising tourism worldwide.

Finally, museums have become a necessity for all, thus these constantly evolving cultural institutions should be of rightful importance to everyone, especially in its re configurations and transformations.

\section{References}

Al-Asad, M., \& Zureikat, L. (2005). The National Gallery of Fine Arts Park: Sculpture Garden and Water-Conserving Model Park. [Online] available:http://www.csbe.org/the-national-gallery-of-fine-arts-park/(Accessed 9 August 2018).

Alivizatou, M. (2012). Intangible Heritage and the Museum; Critical Cultural Heritage Series; Left Coast Press Inc.: Walnut Creek, CA, USA.

Ambrose, A., \& Paine, C. (2005). Museum Basics, ICOM in conjunction with Routledge London \& New York. https://doi.org/10.4324/9780203018989

Ambrose, T., \& Paine, C. (2006). Museum Basics, 2nd edn. London: Routledge.

Ammon news. (2018). Tourism": a significant increase in the contribution of tourism income in the GDP". [Published in Arabic], [Online]available: https://www.ammonnews.net/article/383923(Accessed 27 May 2018).

Ammon news. (2018). "Annab: 487 million dinars tourism income for the month of August, ALLAH perpetuates his grace". [Published in Arabic],[Online]available:https://www.ammonnews.net/article/398613(Accessed 18September 2018).

Balan, M., Vasile, V., (2015). Heritage as an Alternative Driver for Sustainable Development and Economic Recovery in South East Europe Cultural determinants of economic performance in Romania. Procedia - Social and Behavioral Sciences 188, 290 - 296.

Bani Mustafa, A. (2017). Tourism figures during 2017 higher than expected - minister. [Online] available: http://www.jordantimes.com/news/local/tourism-figures-during-2017-higher-expected-\%E2 \%80\%94-minister(Accessed 29 May 2018).

Bruner, E. (1993). Special Issue museums and tourism. Museum Anthropology, 17(3). https://doi.org/10.1525/mua.1993.17.3.6

Freij, M. (2014). 'Mobile art museum to promote tourism careers among young Jordanians'. [Online]

available:http://www.jordantimes.com/news/local/mobile-art-museum-promote-tourism-caree rs-among-young-jordanians\%E2\%80\%99(Accessed 2 September 2018). 
Frey, B.S. \& Meier, S. (2006). The Economics of Museums. Handbook of the Economics of Art and Culture, 1. Elsevier B.V. Amsterdam. https://doi.org/10.1016/S1574-0676(06)01029-5

Gharaibeh, S. (2017). '1,001 Inventions' launches interactive scientific exhibition.[Online]available:http://www.jordantimes.com/news/local/1001-inventions $\% \mathrm{E} 2 \%$ 80\%99-launches-interactive-scientific-exhibition(Accessed 19 May 2017).

Goussous, S. (2016). JICA supporting 'eco-museum' in Salt to showcase daily life, traditions. [Online] available: http://www.jordantimes.com/news/local/jica-supporting-eco-museum-salt-showcase-daily-lif e-traditions(Accessed 9 September 2018).

Goussous, S. (2016). Ain Ghazal statue to be displayed at Abu Dhabi Louvre - official. [Online] available: http://www.jordantimes.com/news/local/ain-ghazal-statue-be-displayed-abu-dhabi-louvre-\%E 2\%80\%94-official(Accessed 17 September 2017).

International Council of Museums. (2007), Museum Definition. 21st General Conference of ICOM, Vienna [Onstria). available: http://icom.museum/en/activities/standards-guidelines/museum-definition/(Accessed $\quad 10$ August 2018)

Johan, N., \& M. Joppe. (2005). Cultural-Heritage Tourism: Review of Existing Market Research. Ottawa: Federal Provincial Territorial Cultural/Heritage and Tourism Initiative.

Jordan Post. (2017). Stamp Museum. [Online] available: http://jordanpost.com.jo/en/stamp-museum(Accessed 25 July 2018).

Jordan Times. (2014). Automobile museum charts Kingdom's history. [Online] available:http://www.jordantimes.com/news/local/automobile-museum-charts-kingdom\%E2 \%80\%99s-history(Accessed 11 June 2018).

Jordan Times. (2014). Queen Rania visits La Storia Museum in Madaba.[Online] available:http://www.jordantimes.com/news/local/queen-rania-visits-la-storia-museum-mada ba(Accessed 15 January 2018).

Jordan Times. (2016). 'Work on JICA-funded Petra Museum project starts in 2017'. [Online] available:

http://www.jordantimes.com/news/local/work-jica-funded-petra-museum-project-starts-2017 $\%$ E2\%80\%99 (Accessed 22 April 2018).

Jordan Times. (2018). King opens Royal Tank Museum. [Online] available:http://www.jordantimes.com/news/local/king-opens-royal-tank-museum(Accessed 11 March 2018).

Jordan Times. (2018). Tourism income reaches $\$ 3.6$ billion by end of August. [Online] available: 
http://www.jordantimes.com/news/local/\%E2\%80\%98tourism-income-reaches-36-billion-en d-august(Accessed 18September 2018).

Jordan Tourism Board. (2013). Museums. [Online] available: http://international.visitjordan.com/Wheretogo/amman/Museums.aspx(Accessed 25 January 2018).

Kelly, L. (2007). Visitors and learner: Adult Museum visitors learning identities. University of Technology. Sydney.

Leiper, N. (1990). Tourist Attraction Systems. Annals of tourism research, 17(2), 367-384. https://doi.org/10.1016/0160-7383(90)90004-B

Majdoubeh, \& C. Sweiss, (2002). The University of Jordan, Jordan University Press, Amman, p 91.

Malt, C. (2002). Museums of Jordan: A Directory, ETHOS Publishing, Florida.

Minchetti, V. Moretti, A., \& Micelli. S. (2002). Reengineering the museum's role in the tourism value chain: towards an it business model. Information technology and tourism, 4, 131-143.

Ministry of Tourism \& Antiquities. (2018). exhibitions. [published in Arabic][Online] available:http://www.doa.gov.jo/inside.php?src=sublinks\&SIID=5012\&MlID=3(Accessed 25 February 2018).

Ministry of Tourism \& Antiquities. (2018). Units and Directorates. [Online] available:http://www.doa.gov.jo/En/inside.php?src=sublinks \&SIID=5052\&MIID=5002(Acce ssed 25 February 2018).

Ministry of Tourism \& Antiquities. (2018). Museums. [Online] available: http://doa.gov.jo/en/inside.php?src=M1\&M1ID=10(Accessed 19 February 2018).

Naghway, A. (2007). 'The contribution of Jordan in discover Islamic art project', in Proceeding Crossing Jordan, the 10th International Conference on the History and Archaeology of Jordan, 23-28 May 2007,Washington,D.C[Online] available:http://www.ichaj.org/ichaj10/academic-program.html\#5B.(Accessed 12 December 2017).

Ngwira, C. \& Bello, G, F. (2018). Museums as a vehicle for domestic tourism growth in Malawi: an analysis of the push and pull factors. [Online] available: https://www.ajhtl.com/uploads/7/1/6/3/7163688/article_20_vol_7_1_2018.pdf (Accessed 7 June 2018).

Prieto, A. (2017). Jordan Museum pays homage to Leonardo Da Vinci's machines. [Online]available:http://www.jordantimes.com/news/local/jordan-museum-pays-homage-leon ardo-da-vinci\%E2\%80\%99s-machines(Accessed 16 March 2018).

Royal Hashemite Court, (2018). King inaugurates Prophet Mohammad Museum online available: 


\section{Macrothink}

Journal of Management Research

ISSN 1941-899X 2019, Vol. 11, No. 1

https://kingabdullah.jo/en/news/king-inaugurates-prophet-mohammad-museum(Accessed 19 January 2018).

S. Mousa. (1985). Amman the Capital of Jordan, Municipality of the Capital's Publications, Amman, p 109.

Steven, T. and Simon, M. (1999). Museums: A supply-side perspective. Annals of tourism research, 26(3), 613-631. https://doi.org/10.1016/S0160-7383(99)00024-9

The children's Museum Jordan. (2018). About Us. [Online]available: http://www.cmj.jo/content/about-us(Accessed 22 January 2018).

The children's Museum Jordan. (2018). OUR MOBILE MUSEUM. [Online] available: http://www.cmj.jo/content/our-mobile-museum-0(Accessed 22 January 2018).

Touche, R. (1989). Museums Funding and Services: The visitor perspective, Report of a survey carried out by Touche Ross Management Consultants, London.

World Monuments Fund. (2017). Temple of Zeus. [Online] available: https://www.wmf.org/project/temple-zeus.(Accessed 27 February 2018).

Zaghloul, M. (1994). The Jordan Archaeological Museum, DOA, Amman. 